Ethiopian Journal of Environmental Studies \& Management 10(4): 530 - 542, 2017.

ISSN:1998-0507

doi: https://dx.doi.org/10.4314/ejesm.v10i4.10

Submitted: February 23, 2017

Accepted: June 01, 2017

\title{
SINGLE AND JOINT ACTION TOXICITY EVALUATION OF INSECTICIDE AND LAUNDRY DETERGENT AGAINST Poecilia reticulata
}

\author{
*OSUALA, F.I., ${ }^{1}$ SAMUEL, O.B., ${ }^{2}$ ABIODUN, O.A., ${ }^{3}$ IGWO-EZIKPE, M.N., ${ }^{4}$ \\ KEMABONTA, K.A. ${ }^{1}$ AND OTITOLOJU, A.A. ${ }^{1}$ \\ ${ }^{1}$ Department of Zoology, Faculty of Science, University of Lagos, P.M.B. 101017, Lagos, \\ Nigeria \\ ${ }^{2}$ Department of Marine, Faculty of Science, University of Lagos, P.M.B. 101017, Lagos, \\ Nigeria \\ ${ }^{3}$ Department of Biochemistry, Faculty of Basic Medical sciences, College of Medicine, \\ University of Lagos, P.M.B. 12003, Lagos, Nigeria \\ ${ }^{4}$ Biological Oceanography Department, Nigerian Institute for Oceanography and Marine \\ Research, Lagos State, Nigeria
}

\begin{abstract}
In laboratory bioassays, single action toxicities of an insecticide (Apicide [A]) and two laundry detergents (Persil [P] and Klin [K]) as well as their joint action toxicity studies in binary (1:1; 1:4) and triple (1:1:1) mixtures were evaluated against Poecilia reticulata (Guppy). Joint action toxicity mortality data was analyzed using Synergistic Ratio (SR), Concentration - Addition (RTU) and Isobolograms models. On the basis of $96 \mathrm{hr} L C_{50}$ mortality data from single action studies, showed that $A$ was the most toxic $(0.00137 \mathrm{mg} / \mathrm{l})$ followed by $P(0.773 \mathrm{mg} / \mathrm{l})$ and $K$ $(28.841 \mathrm{mg} / \mathrm{l})$. The joint action toxicity data showed a synergistic effect in mixtures of insecticide and detergents in all ratios (1:1, 1:4, 1:1:1) than when acting alone. In descending order of toxicity it was revealed that Apicide/persil (1:1; 0.00079mg/l)>Apicide/ Persil/Klin (1:1:1; $\quad 0.00093 \mathrm{mg} / \mathrm{l})>$ Apicide/Klin $\quad(1: 1 ; \quad 0.00094 \mathrm{mg} / \mathrm{l})>$ Apicide/ Persil (1:1; $0.00098 \mathrm{mg} / \mathrm{I})>$ Apicide/ Klin $(1: 4 ; 0.00106 \mathrm{mg} / \mathrm{l})$. The subjection of the $96 \mathrm{~h} L \mathrm{C}_{50}$ values of test compound mixtures based $S R$ and RTU showed that interaction of mixtures in various ratios $(1: 1,1: 4,1: 1: 1)$ tended towards synergisms (SR>1; RTU>1) respectively. Further analysis based on the isobologram model was in conformity with RTU and SR models. The significance of this study showed the relevance of joint action toxicity studies in setting realistic safe limits in order to protect aquatic organisms. Therefore, proper disposal and management strategies for wastes should be enforced.
\end{abstract}

Key Words: Bioassay, Detergent, Insecticide, Toxicity, Poecilia reticulata

Introduction

Man's domestic and industrial activities introduce several chemicals into the environment which impact living organisms in the ecosystem depending on the concentration and duration of exposure. Insecticides constitute one of the major groups of pollutants deliberately introduced into the environment to exploit their toxic action 
against pests in domestic, agricultural, and medical sectors. Insecticides are economic poisons, designed to kill or repel pest which is the fastest, easiest, and therefore, the most common method of pest control above cultural and biological methods (Don-Pedro, 1980). However, continued over-reliance on chemical method of control is limited by deleterious side effects on non-target species including aquatic organism, livestock-wildlife, and man coupled with the development of resistant pest species (Don-Pedro, 1993; Don-Pedro and Adebite, 1985). There has been largescale destruction of aquatic resources such as fish, crabs, crayfish and tadpoles (Wigglesworth, 1976). These compounds occur in many aquatic ecosystems with other pollutants such as detergents. In dwelling places several kinds of detergents are used as cleaning agents obtained from synthetic organic chemicals (Ogundiran et al., 2010). The Nigerian market is flooded with varied brands of detergents manufactured by companies locally and internationally in order to meet the need of the growing population. Most of these detergents are cheap and foams easily with all forms of water whether acid or hard (Okpokwasili and Nwabuzor, 1988). The major culprit that enhances the cleaning ability of these detergents aside from bleach, builders, dyes, enzymes filler, foam stabilizer, optical brighteners, perfume, soilsuspending agents, and other materials is surfactants (Swisher, 1975; Okpokwasili and Nwabuzor, 1988). However, detergents eventually chart their entry into the aquatic environment impacting the biotic components (Adham et al., 2002; Adewoye and Fawole, 2002; Adewoye et al., 2005; Ogundiran et al.,
2007 and Ogundiran et al., 2009). Detergents bioaccumulate in an aquatic organism (Dara, 1993), biomagnify in the food chain (Farkas et al., 2002) resulting in cell damage (Chibuzor, 1994). Numerous studies have investigated the single action toxicity of these pollutants (Otitoloju and Okusada, 2003; Adebayo, 2006) ignoring the fact that these pollutants (detergent and insecticides) occur as mixtures impacting organisms in the aquatic environment. Therefore, to understand potential impacts on non-target organisms in these habitats, toxicologists generally use short-term (4-d) toxicity tests on model organisms. Considering the management of pollution, single and joint action toxicity studies of chemicals against nontarget organisms is necessary. Thus the study investigated the biological action of insecticide and detergents acting singly and jointly against a local aquatic species that is of ecological significance.

\section{Materials and Methods Test Animals}

Adult Poecilia reticulata $(0.08 \mathrm{~g} \pm$ $0.01 ; 16 \mathrm{~mm} \pm 0.002)$ were collected using a sweep net (Mesh size $2 \mathrm{~mm}$ ) from an open drainage located at the University of Lagos. They were transported in transparent bags containing water from the point of collection to the laboratory into a holding plastic tank (30L) half filled with a mixture of dechlorinated tap water and water from the site of collection. Throughout the duration of the experiments, guppies were collected from the same site to minimize variability in biotype.

\section{Acclimatization of Test Animals}

$P$. reticulata were acclimatized to laboratory conditions at $28^{\circ} \mathrm{C} \pm 2{ }^{\circ} \mathrm{C}$ and 
$79.5 \% \pm 2 \mathrm{RH}$ for 9days before being used in bioassays and fed with fish pellets daily. Water in holding tanks was changed once every four days to avoid the accumulation of waste metabolites and decaying food substances.

\section{Test Compounds}

The test compounds evaluated were; a household insecticide coded as A and two commonly used laundry detergents coded as $\mathrm{K}$ and $\mathrm{P}$.

\section{Insecticide (A)}

It is a pyrethroid, colourless, emulsifiable concentrate, which volatilizes in nature. It is used as a domestic insecticide. The constituent as stated by the manufacturer were:

Dichlorodivinyl phosphate (DDVP) + mixed pyrethroid $0.90 \% \mathrm{w} / \mathrm{W}$

Solvents + Perfume $99.10 \% \mathrm{w} / \mathrm{w}$ Manufactured by AP Plc., and purchased at a supermarket in Festac -Town, Lagos.

\section{Detergent $(P)$}

It is a white powdery substance and non-biological washing powder manufactured and distributed by Lever Brothers Ltd. in Ireland and Nigeria respectively. It was purchased in a supermarket located at Festac-Town, Lagos. Their constituents as stated by the manufacturer on the container were:

Soap polycarboxylate $\quad<5 \%$

Anion Surfactant 3-15\%

Oxygen based bleaching agent 5-15\%

Phosphates 15-30\%

Brightening agent undefined

Detergent (K)

It is white, powdery and crystalline in nature used for washing fabrics manufactured by P.T. Sayeb, Indonesia. It was purchased in a supermarket located in Festac-Town, Lagos. Its constituents as stated by the manufacturer on the container were as follows:

Linear Alkyl Benzene Sulfonate (LABS)

Sodium Trioxocarbonate (IV) $\left(\mathrm{Na}_{2} \mathrm{Co}_{3}\right)$

Sodium Trioxosulphate (VI) $\left(\mathrm{NaSO}_{4}\right)$

General Bioassay Techniques

Bioassay Containers

Plastic containers (bottom diameter $=$ $30 \mathrm{~cm}$, volume $=3 \mathrm{~L}$ ) served as bioassay containers in all experiments.

\section{Preparation of Test Media}

Based on the preliminary test conducted, various concentrations were determined for the test compounds. It was weighed out for the detergent solid formulation while the insecticide formulation was measured out by volume and each measure was filled up to $1000 \mathrm{ml}$ in a conical flask to achieve a stock solution of known strength, using distilled water as diluents. The stock solutions were serially diluted to achieve solutions of lower strengths. To prepare a test media, an amount of the stock solution or serially diluted solution was taken out by a measuring cylinder and poured into a bioassay container where it is made up to $1000 \mathrm{ml}$ using the appropriate amount of dechlorinated tap water as diluents. Preliminary experiments demonstrated that $1000 \mathrm{ml}$ of dechlorinated tap water could support ten guppies for 10days without aeration. Thus all test media including control were always made up to $1000 \mathrm{ml}$.

\section{Quantal Response (Mortality) Assessment}

Test animals were taken to be dead when all body parts stopped movement even when probed with a glass rod. Mortality was assessed once every 24hours for a period of 4days for all the experimental set - up. 
Relative Acute Toxicity of Detergents and Insecticides Acting Singly against $P$. reticulata

Active guppies (10) of similar sizes were randomly assigned to insecticide and detergent treated and untreated test media, in separate duplicate bioassay containers.

\section{Bioassay Procedure}

The bioassay procedure was without renewal of the test medium that was applied for all toxicity tests. The following concentrations for the insecticide and laundry detergents that were tested against the test animals on single action toxicity were as follow:

A (mg/l): 0.00072, 0.00090, 0.00108, $0.00144, \quad 0.00162,0.00216,0.00234$, 0.00290 and control

$\boldsymbol{K}(\mathrm{mg} / \mathrm{l}): 10.00,20.00,25.00,30.00$, $40.00,50.00,60.00,70.00,80.00$ and control

$\boldsymbol{P}(\mathrm{mg} / \mathrm{l}): 0.25,0.30,0.50,1.50,1.60$, $1.65,1.80,1.90,2.00$ and control

\section{Joint Action Toxicity of Insecticide and} Laundry Detergent

The joint action toxicity test is a similar experiment with that of acute toxicity test, but in this case, the test media contained a mixture of insecticide and laundry detergents in the following ratio:

(a) Binary $1: 1 ; 1: 4$ mixtures of $\mathrm{A}$ and $\mathrm{P}$ or $\mathrm{K}$ detergent

(b) Triple 1:1:1 mixture of $\mathrm{A}, \mathrm{P}$ and $\mathrm{K}$ detergent.
Guppies were exposed to the following experimental concentrations of test mixtures as follows:

Binary mixtures containing a $1: 1$ ratio of A insecticide and $\mathrm{K}$ detergent: 0.00065 , $0.00072,0.00090$, $0.00100, \quad 0.00108,0.00130,0.00144$, $0.01550,0.00162$ and untreated control

Binary mixtures containing a 1:4 ratio of A insecticide and $\mathrm{K}$ detergent: 0.00072, 0.00090 ,

$0.00144, \quad 0.00162, \quad 0.000170$ and untreated control.

Triple 1:1:1 mixture of $\mathrm{A}$ insecticide, $\mathrm{P}$ and $\mathrm{K}$ detergent: 0.000720 .00075 , $0.00108,0.00144$.

$0.00165,0.00170$ and untreated control.

\section{Statistics}

Dose-response mortality data were analyzed by Probit analysis after Finney (1971) using SPSS 10.0 and implemented by Ge Le Pattourriee, imperial college, London as adopted by Don - Pedro (1989).

$\mathrm{LC}_{50}$ : the lethal concentration that can cause mortality in $50 \%$ of the population.

Joint action toxicity mortality data was analyzed using three (3) models (A, B, and $\mathrm{C}$ ).

$>$ Model A: a model after Hewlett and Plackett (1959) was adopted in this study to classify and quantify the joint action of detergents and insecticide that are separately active against the guppies as follows:

Synergistic Ratio (SR): the index for measuring synergism

$\mathrm{SR}=96 \mathrm{hr} \mathrm{LC}_{50}$ chemical acting alone (e.g. Test Insecticide)

96hr $\mathrm{LC}_{50}$ of mixture (Insecticide and Detergent) 
Evaluation when:

$>$ S.R $=1$ additive interaction

$>$ S.R $<1$ Antagonistic interaction

$>$ S.R $>1$ Synergistic interaction

$>$ Model B: Concentration addition model (Anderson and Weber, 1975). This model assumes that when similarly acting toxicants are mixed in any proportion they will add together to give the observed response in evaluating the joint-action. A predicted a response value ( $\mathrm{s}$ ) is derived by summing up the $\mathrm{LC}_{50}$ values of the separate toxicants according to the proportion of their contribution in the mixture. It is then compared to the observed $\mathrm{LC}_{50}$ value of the mixture to classify the type of interaction as follows:

Evaluation when:

$>\mathrm{LC}_{50}$ values of mixture is $=$ or $<$ or $>$ than Predicted $\mathrm{LC}_{50}$ value, it is Additive or Synergistic or Antagonistic interaction respectively.

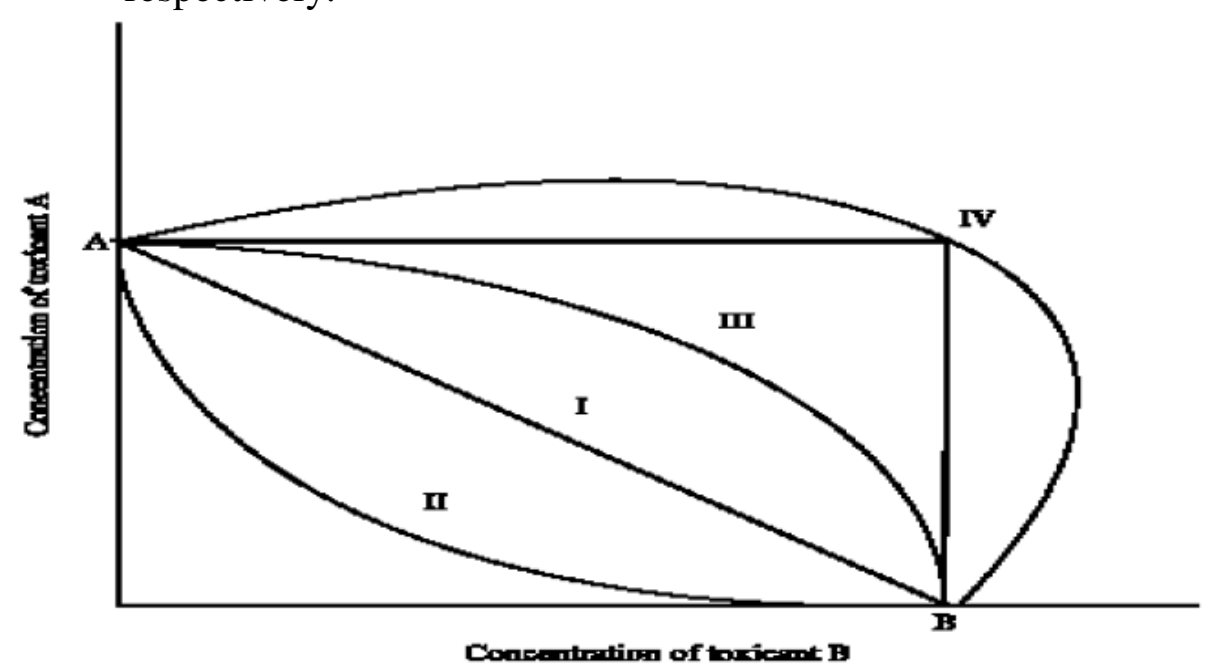

Fig. 1: Isoboles depicting the types of interactions between two chemicals A and B (Ariens et al., 1976). Isobole I, II, III and IV depict additive, synergism, subadditive and antagonism respectively
$>$ The relationship of derived $\mathrm{LC}_{50}$ values to predicted $\mathrm{LC}_{50}$ (RTU, Relative Toxicity Unit) is estimated as:

$>\mathrm{RTU}=$ Predicted $\mathrm{LC}_{50}$ value Experimentally derived $\mathrm{LC}_{50}$ where it is

$>$ Additive RTU $=1$

$>$ Antagonism RTU $<1$

$>$ Synergism RTU $>1$

Model C: Isobolograms (Ariens et al., 1976). The joint action toxicity between the toxic compounds is presented in form of isobolograms. Each Isobole (I - IV) represent the amount of the toxicants in the formulations (employing multiple ratios with mixtures with the same constituents but in varying ratios) that produce a given biological response (usually the $50 \%$ mortality response level- $\mathrm{LC}_{50}$ ). In the theoretical isobole, points $\mathrm{A}$ and $\mathrm{B}$ represent the amounts of toxicant $\mathrm{A}$ and $\mathrm{B}$ which singly produced the biological response ( $\mathrm{LC}_{50}$ or median response levels in this research) which when connected gives the additive line (figs.1). 


\section{Results}

Relative acute toxicity of $A, P$ and $K$ acting singly against $P$. reticulata

On the basis $96 \mathrm{hr}$ derived mortality data, it showed that insecticide (A) was most toxic $(0.00137 \mathrm{mg} / \mathrm{l})$ followed by detergents $\mathrm{P} \quad(0.773 \mathrm{mg} / \mathrm{l})$ and $\mathrm{K}$ $(28.841 \mathrm{mg} / \mathrm{l})$. Based on the derived Toxicity Factor (TF) insecticide (A) was 21051.82X more toxic than K (Table 1).

Joint action toxicity of insecticide and detergents against $P$. reticulata

On the basis of $96 \mathrm{~h} \mathrm{LC}_{50}$ joint action toxicity data values (Table 2), showed that the mixtures of insecticide and detergents in all ratios $(1: 1,1: 4,1: 1: 1)$ was more toxic to $P$. reticulata than when acting alone $(\mathrm{A}=0.00137 \mathrm{mg} / \mathrm{l}$; $\mathrm{P}=0.773 \mathrm{mg} / \mathrm{l}$ and $\mathrm{K}=28.841 \mathrm{mg} / \mathrm{l})$. In descending order of toxicity it was revealed that $\mathrm{A} / \mathrm{P}(1: 1 ; 0.00079 \mathrm{mg} / \mathrm{l})>$ $\mathrm{A} / \mathrm{P} / \mathrm{K}(1: 1: 1 ; 0.00093 \mathrm{mg} / \mathrm{l})>\mathrm{A} / \mathrm{K}(1: 1$;
$0.00094 \mathrm{mg} / \mathrm{l})>\mathrm{A} / \mathrm{P}$

$0.00098 \mathrm{mg} / \mathrm{l})>\mathrm{A} / \mathrm{K}(1: 4 ; 0.00106 \mathrm{mg} / \mathrm{l})$.

Subjection of joint action toxicity data based on Synergistic Ratio model (SR) showed a similar trend where all mixtures was far above $1 \quad(\mathrm{SR}>1)$ indicating synergism. The derived $\mathrm{SR}^{2}$ in all mixtures were also greater than 1 (Table 3).

Subjection of the $96 \mathrm{~h} \mathrm{LC}_{50}$ values to synergistic analysis of test compound mixtures (Based on Concentration Addition Model) showed that interaction of mixtures in various ratios $(1: 1,1: 4$, $1: 1: 1)$ tended towards synergisms (RTU>1) although varying in different levels of fit (Table 4).

Further analysis of joint action toxicity data based on the isobologram model showed that in binary mixtures (1:1 and 1:4), the Isoboles was inclined to synergism (figs. 2 and 3 ).

Table 1: Relative Toxicity of A, $\mathrm{P}$, and $\mathrm{K}$ on Poecilia reticulata

\begin{tabular}{|c|c|c|c|c|}
\hline Exposure Time(hr) & $\mathrm{LC}_{50}(95 \% \mathrm{CL}) \mathrm{mg} / \mathrm{l}$ & Slope \pm SE & Probit line equation & $\mathrm{TF}$ \\
\hline \multicolumn{5}{|c|}{ A } \\
\hline 24 & $0.00216(0.00187-0.00259)$ & $5.22 \pm 1.12$ & $Y=18.92+5.22 X$ & \\
\hline 48 & $0.00185(0.00185-0.00185)$ & $4.64 \pm 0.81$ & $Y=17.69+4.64 X$ & \\
\hline 72 & $0.00157(0.00139-0.00175)$ & $6.05 \pm 0.90$ & $Y=21.97+6.05 X$ & \\
\hline 96 & $0.00137(0.00117-0.00155)$ & $4.90 \pm 0.76$ & $Y=19.04+4.90 X$ & 21051.82 \\
\hline 24 & \multicolumn{4}{|c|}{$\mathrm{P}$} \\
\hline 48 & $1.207(0.915-1.527)$ & $2.42 \pm 0.52$ & $Y=4.80+2.42 X$ & \\
\hline 72 & $0.972(0.364-1.232)$ & $2.07 \pm 0.35$ & $Y=5.03+2.07 X$ & \\
\hline 96 & $0.773(0.375-1.187)$ & $2.51 \pm 0.36$ & $Y=5.28+2.51 X$ & 28.07 \\
\hline \multicolumn{5}{|c|}{$\mathrm{K}$} \\
\hline 24 & $38.473(31.977-49.138)$ & $3.18 \pm 0.59$ & $Y=-0.05+3.18 X$ & \\
\hline 48 & $35.616(28.259-45.979)$ & $2.89 \pm 0.53$ & $Y=0.52+0.53 X$ & \\
\hline 72 & $28.841(21.557-37.128)$ & $4.60 \pm 0.61$ & $Y=-1.72+4.60 X$ & \\
\hline 96 & $28.841(21.557-37.128$ & $4.60 \pm 0.61$ & $Y=-1.72+4.60 X$ & 1.00 \\
\hline
\end{tabular}

$\mathrm{CL}=$ Confidence limit, $\mathrm{SE}=$ Standard error ; Toxicity factor $(\mathrm{TF})=96 \mathrm{~h} \mathrm{LC}_{50}$ value of $\mathrm{K} / 96 \mathrm{~h} \mathrm{LC}_{50}$ value of $\mathrm{A}, \mathrm{P}$ and $\mathrm{K}$ 
Table 2: Joint Action Toxicity of A, $\mathrm{P}$, and $\mathrm{K}$ Mixture against $P$. reticulata

\begin{tabular}{|c|c|c|c|c|}
\hline Exposure Time (hr) & $\mathrm{LC}_{50}(95 \% \mathrm{CL}) \mathrm{mg} / \mathrm{l}$ & Slope \pm SE & Probit line equation & $\mathrm{TF}$ \\
\hline \multicolumn{5}{|c|}{$\mathrm{A} / \mathrm{K}(1: 1)$} \\
\hline 24 & $0.00216(0.00117-0.00136)$ & $9.57 \pm 1.97$ & $Y=32.73+9.57 X$ & \\
\hline 48 & $0.00112(0.00102-0.00123)$ & $6.32 \pm 1.07$ & $Y=23.64+6.32 X$ & \\
\hline 72 & $0.00101(0.00091-0.00111)$ & $5.74 \pm 0.87$ & $\mathrm{Y}=22.20+5.74 \mathrm{X}$ & \\
\hline 96 & $0.00094(0.00086-0.00103)$ & $6.60 \pm 0.93$ & $Y=24.97+6.60 X$ & 1.13 \\
\hline \multicolumn{5}{|c|}{$\mathrm{A} / \mathrm{K}(1: 4)$} \\
\hline 24 & $0.00127(0.00111-0.00144)$ & $5.27 \pm 1.02$ & $\mathrm{Y}=20.27+5.57 \mathrm{X}$ & \\
\hline 48 & $0.00119(0.00104-0.00135)$ & $5.31 \pm 1.00$ & $Y=20.51+5.31 X$ & \\
\hline 72 & $0.00113(0.00101-0.00127)$ & $5.79 \pm 1.02$ & $Y=22.27+5.79 X$ & \\
\hline 96 & $0.00106(0.00089-0.00115)$ & $4.67 \pm 0.94$ & $Y=18.89+4.67 X$ & 1.00 \\
\hline \multicolumn{5}{|c|}{$\mathrm{A} / \mathrm{P}(1: 1)$} \\
\hline 24 & $0.00118(0.00107-0.00129)$ & $6.46 \pm 1.15$ & $Y=23.92+6.46 X$ & \\
\hline 48 & $0.00113(0.00104-0.00124)$ & $6.52 \pm 1.15$ & $Y=24.20+6.52 X$ & \\
\hline 72 & $0.00100(0.00090-0.00110)$ & $6.98 \pm 1.32$ & $Y=-25.94+6.98 X$ & \\
\hline 96 & $0.00098(0.00091-0.00106)$ & $8.63 \pm 1.27$ & $Y=30.96+8.63 X$ & 1.08 \\
\hline \multicolumn{5}{|c|}{$\mathrm{A} / \mathrm{P}(1: 4)$} \\
\hline 24 & 0.00087 (0.00074-0.00098) & $5.18 \pm 0.93$ & $Y=20.86+5.18 X$ & \\
\hline 48 & $0.00082(0.00069-0.00093)$ & $5.69 \pm 1.14$ & $Y=22.56+5.69 X$ & \\
\hline 72 & $0.00080(0.00072-0.00088)$ & $6.40 \pm 1.26$ & $Y=24.80+6.40 X$ & \\
\hline 96 & 0.00079 (0.00069-0.00088) & $6.38 \pm 1.27$ & $Y=24.79+6.38 X$ & 1.34 \\
\hline \multicolumn{5}{|c|}{ A/ K/P (1:1:1) } \\
\hline 24 & $0.00136(0.00120-0.00158)$ & $5.12 \pm 0.97$ & $Y=19.67+5.12 X$ & \\
\hline 48 & $0.00120(0.00103-0.00138)$ & $4.24 \pm 0.80$ & $\mathrm{Y}=17.38+4.24 \mathrm{X}$ & \\
\hline 72 & $0.00104(0.00090-0.00117)$ & $4.62 \pm 0.79$ & $Y=18.77+4.62 X$ & \\
\hline 96 & $0.00093(0.00081-0.00106)$ & $6.56 \pm 1.07$ & $Y=24.55+6.57 X$ & 1.14 \\
\hline
\end{tabular}

$\mathrm{CL}=$ Confidence limit; $\mathrm{SE}=$ Standard error; $\mathrm{TF}=$ Toxicity factor $=96 \mathrm{LC}_{50}$ value of A:K (1:4) $/ 96 \mathrm{~h} \mathrm{LC}_{50}$ value of A:K (1:1), A: P (1:1), A: P (1:4), and A: K: P (1:1:1)

Table 3: Analysis (Based on Synergistic Ratio Model) of the 96h $\mathrm{LC}_{50}$ Values of Test Compound when acting Jointly or Singly Tested against Poecilia reticulata

\begin{tabular}{lllll}
\hline Text compound mixtures & $\mathrm{LC}_{50}$ values $(95 \% \mathrm{CL}) \mathrm{mg} / \mathrm{l}$ & $\mathrm{SR}^{1}$ & $\mathrm{SR}^{2}$ & $\mathrm{SR}^{3}$ \\
\hline $\mathrm{A}: \mathrm{K}(1: 1)$ & $0.00094(0.00086-0.00103)$ & 1.46 & 30681.92 & - \\
$\mathrm{A}: \mathrm{K}(1: 4)$ & $0.00106(0.00089-0.00115)$ & 1.29 & 27208.49 & - \\
$\mathrm{A}: \mathrm{P}(1: 1)$ & $0.00098(0.00091-0.00106)$ & 1.40 & 788.78 & - \\
A:P $(1: 4)$ & $0.00079(0.00069-0.0008$ & 1.73 & 978.48 & - \\
A:K: $\mathrm{P}(1: 1: 1)$ & $0.00093(0.00081-0.00106)$ & 1.47 & 31011.83 & 831.18 \\
A alone & $0.00137(0.00117-0.00155)$ & & & \\
K alone & $28.841(21.557-37.128)$ & & & \\
P alone & $0.773(0.375-1.187)$ & & & \\
\hline
\end{tabular}

$\mathrm{CL}=95 \%$ Confidence limit; $\mathrm{SR}^{1}$ or $\mathrm{SR}^{2}$ or $\mathrm{SR}^{3}=1$ indicates additive action; $\mathrm{SR}^{1}$ or $\mathrm{SR}^{2}$ or $\mathrm{SR}^{3}>$ indicates synergism; $\mathrm{SR}^{1}$ or $\mathrm{SR}^{2}$ or $\mathrm{SR}^{3}<$ indicates antagonism; $\mathrm{SR}=\underline{\mathrm{LC}_{50} \text { of a toxicant acting alone }}$ 
Single and Joint Action Toxicity Evaluation of Insecticide.................OSUALA et al.

Table 4: Synergistic Analysis of Test Compound Mixtures (Based on ConcentrationAddition Model) Tested against $P$. reticulata

\begin{tabular}{llll}
\hline Text compound mixtures & $\begin{array}{l}\text { Experimentally Observed } \\
\text { LC }\end{array}$ & Predicted 96h $\mathrm{LC}_{50}(95 \% \mathrm{CL}) \mathrm{mg} / \mathrm{l}$ & $\mathrm{RTU}$ \\
\hline $\mathrm{A}: \mathrm{K}(1: 1)$ & $0.00094(0.00086-0.00103)$ & $14.42119(10.77909-18.57175)$ & 15341.69 \\
A:K $(1: 4)$ & $0.00106(0.00089-0.00115)$ & $23.07307(17.24583-29.70271)$ & 21767.05 \\
A:P $(1: 1)$ & $0.00098(0.00091-0.00106)$ & $0.38719(0.18807-0.59428)$ & 395.09 \\
A:P $(1: 4)$ & $0.00079(0.00069-0.00088)$ & $0.61867(0.30023-0.94991)$ & 783.13 \\
A:K:P $(1: 1: 1)$ & $0.00093(0.00081-0.00106)$ & $9.87179(7.31106-12.77218)$ & 10614.83 \\
\hline
\end{tabular}

$\mathrm{CL}=95 \%$ Confidence limit; Predicted $96 \mathrm{hLC}_{50}=$ Sum total of the single action $96 \mathrm{hLC}_{50}$ values of constituent toxicants according to the proportion of the contribution in the test mixture; RTU $=1$ indicates additive action; RTU $>1$ indicates synergism; RTU $<1$ indicates antagonism RTU (Relative Toxicity Unit) $=$ Predicted 96h LC S0 $_{50}$

Experimentally Observed $96 \mathrm{~h} \mathrm{LC}_{50}$

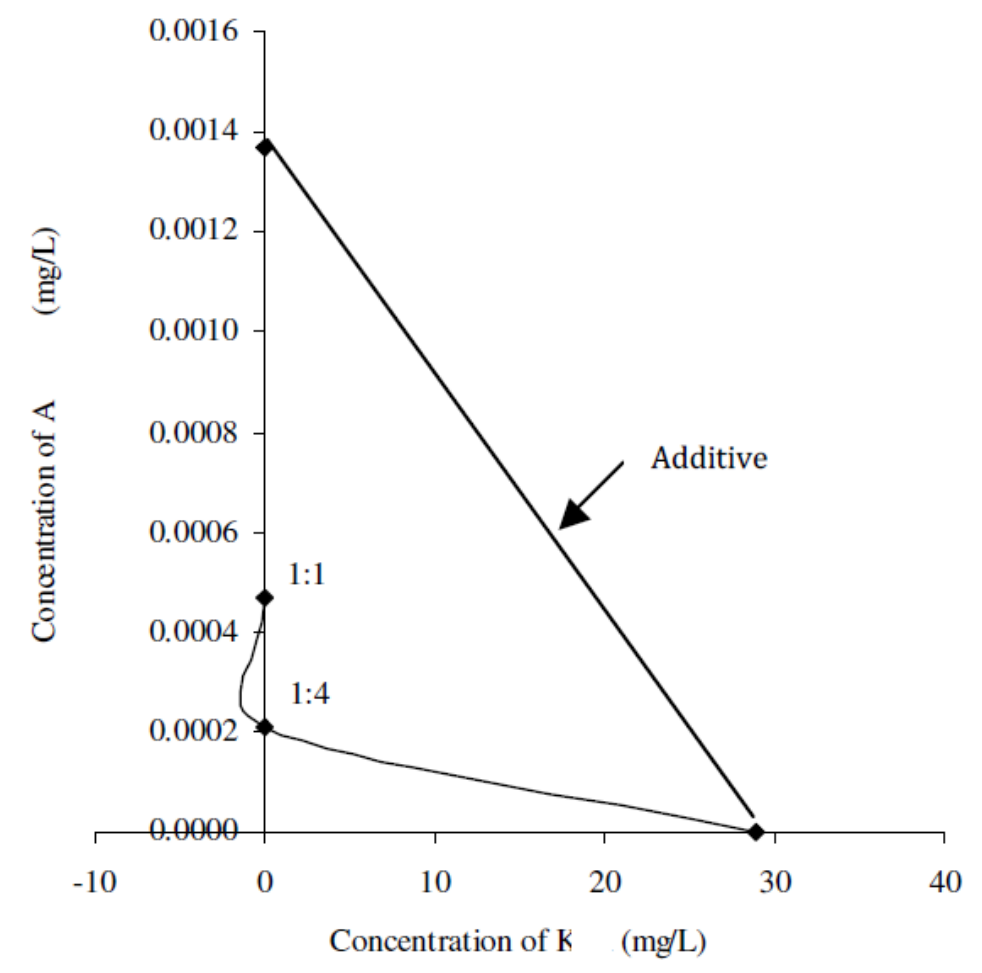

Figure 2: Isobole Representation of the Binary Mixtures Effect of $\mathrm{A}$ and $\mathrm{K}$ at 1:1 and 1:4 when tested against $P$. reticulata 


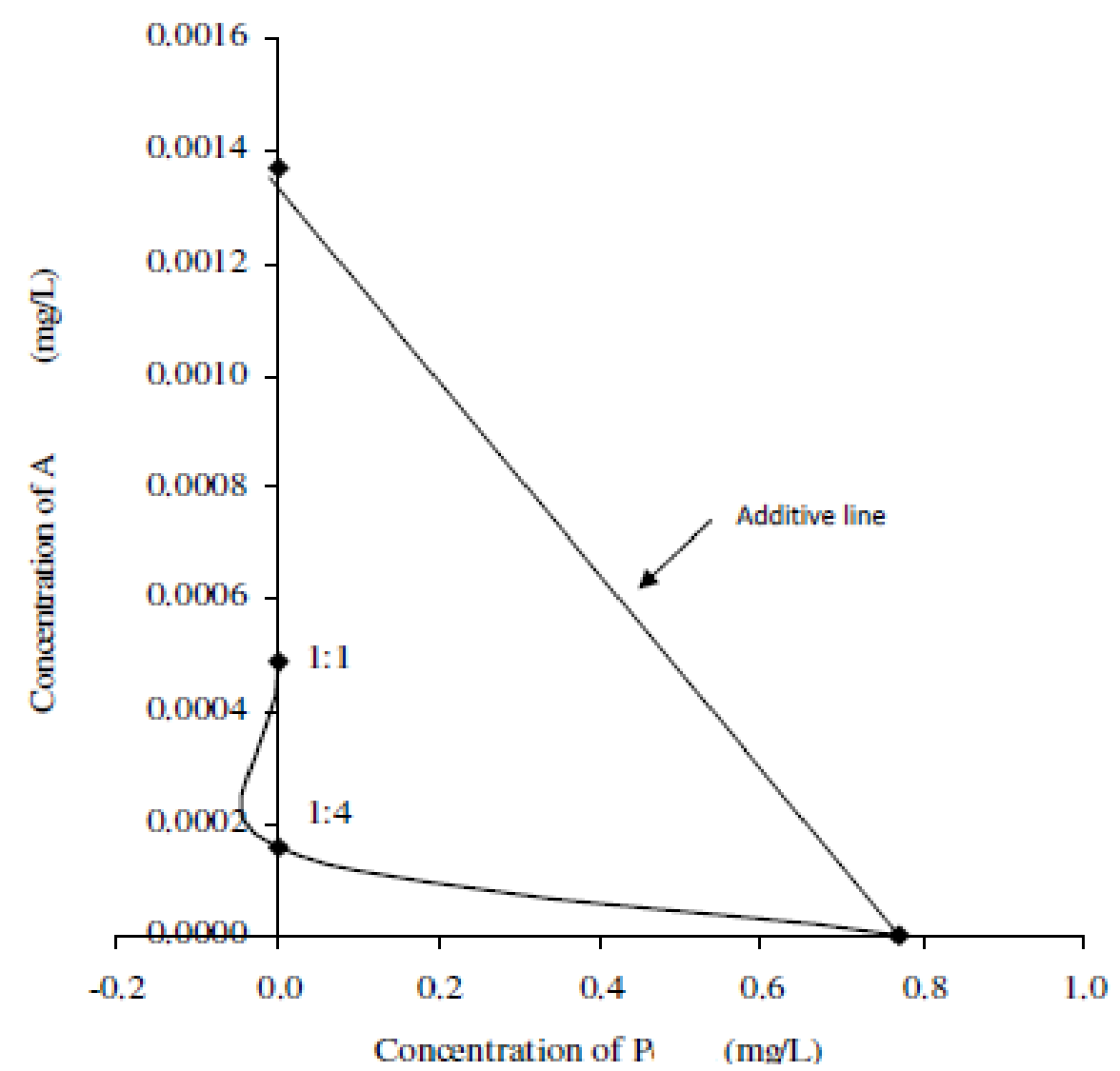

Figure 3: Isobole $\mathrm{P}$-presentation of the Binary Mixtures ${ }^{\mathrm{E} f \mathrm{ect}}$ of $\mathrm{A}$ and $\mathrm{P}$ at 1:1 and 1:4 when tested agains ग. reticulata

\section{Discussion}

The study has established the relative acute and joint action toxicity of insecticide (A) and laundry detergents $(\mathrm{P}$ and $\mathrm{K}$ ) against $P$. reticulata. On the basis of $96 \mathrm{~h} \quad \mathrm{LC}_{50}$ values derived from mortality data of chemicals acting singly against $P$. reticulata which indicated that A was the most toxic followed by $\mathrm{P}$ and $\mathrm{K}$ is in agreement with the findings of Oyekunle (1996), who reported that Nuvan was 1.2 times more toxic when compared to Gardoprim against guppy. Lawal and Samuel (2010) also found out that Actellic, an insecticide was toxic to $P$. reticulata at $96 \mathrm{~h} \quad \mathrm{LC}_{50}$ value of $0.019 \mathrm{mlL}^{-1}$. The differential acute toxicity of pesticide and detergents could probably be ascribed to differences in their physicochemical components (Adebayo, 2004) that also influenced their penetrability into the membranes as well as in their sites and, mechanism of action. This calls for caution in the indiscriminate usage and disposal of insecticide containers. Guppy is a very a hardy species of fish with high tolerance level to polluted water. Their response to the toxic levels of $\mathrm{A}$ is indicative of its biomonitoring quality especially to pesticides as indicated by various studies (Polat et al., 2002; Mahmut et al., 2005; Mehmet et al., 2004 and Rukiye et al., 2003). It also showed that the insecticide could pose high environmental risk to non-target organisms that are 
inadvertently exposed to this pollutant (Medeiros et al., 2013). Additionally, the insecticide (A) being more toxic than the detergents is not surprising as study as shown that insecticides are even more toxic than herbicides (Mhadhbi and Beiras, 2012).

Invariably, aquatic organisms at the receiving end of the water body are thus exposed to these pollutants in mixtures and impacting their effects simultaneously. Therefore, the study on joint action provides better information on the health of the environment than when solely relying on the classical single action toxicity test. The joint action toxicity data that showed the mixtures of insecticide and detergent in all ratios $(1: 1,1: 4,1: 1: 1)$ was more toxic to $P$. reticulata than when acting alone showed synergistic action meaning that the toxicity of the insecticide was enhanced in all ramifications of mixture ratios. This could be traced to the surface acting property of detergents thus imparting their toxicity on the membrane (Enajekpo, 2000). Once there is a lysis of the membrane, the components of the A were probably able to penetrate making it bioavailable to elicit its toxicity. This is also in agreement with the finding of Adebayo (2004) where the author observed that laundry detergents synergized the toxicity of spent lubricating oil against $P$. reticulata. The study revealed that $\mathrm{A}$, and $\mathrm{P}$ mixtures in ratio 1:1 was the most toxic relative to other ratio mixtures. This is probably as a result of the component of $\mathrm{P}$ that has surfactants; the main contributor to the toxicity of detergents. Studies have shown that aside from the other components of detergents such as brighteners, builders, fillers, phosphates and bleach, surfactants is the major culprit causing their toxicity (Otitoloju, 2005: Warne and Schifko, 1999). However, the toxicity was further complicated due to the overall components of the insecticide (A) thus in all mixtures they showed synergism.

The results of all the models used for the joint action interaction classification conformed to synergistic interaction. This further confirms the reliability of the various models in predicting the toxicity of these selected pollutants

In Nigeria, and many developing countries, there is massive use, indiscriminate discharge/ dumping of detergents and insecticide containers into gutters, open drainages and eventually are discharged into aquatic system impacting organism (food web). In view of these findings, it is extremely important that regulators should enforce proper disposal practice, encourage the treatment of sewage before discharge into the environment backed up with stringent measures to curb these menace. Manufacturers of detergents should use a more environmentally friendly ingredient in order to minimize the negative effects on organisms and man eventually.

The additional relevance of this study is hinged on its usefulness in setting environmentally safe limits for these pollutants that can be utilized by regulatory bodies to ensure safety of aquatic organisms.

\section{Conclusion}

The study has established the relative acute toxicity of an insecticide and detergents as well as the synergistic interaction in various mixture ratios against $P$. reticulata. This calls for further research into other forms of 
pollutants in the environment where organisms are forcefully exposed, to curb the gruesome mortality of organisms that play key roles in the food web.

\section{Acknowledgment}

We thank Professor Otitoloju A. A. for direction in carrying out the study and provision of literatures for writing this manuscript.

\section{References}

Adebayo, A. Otitoloju. (2006). Joint action toxicity of spent engine oil and laundry detergent against Poecilia reticulate (Telostei: Poeciliidae). African Journal of Aquatic Science, 31 (1): 125-129.

Adewoye, S.O. and Fawole, O.O. (2002). Acute toxicity of soap and detergent effluent to fresh water Clariasgariepinusfingerlins.African J Sci (In press).

Adewoye, S.O., Fawole, O.O., Owolabi, O.D. and Omotosho, J.S. (2005). Toxicity of cassava wastewater effluents to African catfish: Clarias gariepinus. Ethiop. J. Sci., 28 (7): 189-194.

Adham, K.G., Hamed, S.S. Ibrahim, H.M. and Saleh, R.A. (2002). Impaired functions of Nile Tilapia, Oreochromis niloticus from polluted waters. Acta Hydrochemical et Hydrobiological, 29: 278-288.

Anderson, P.D. and Weber, L.J. (1975). The toxicity to aquatic population of mixtures containing certain heavy metals. In: Proceedings of the International Conference on heavy metal in the environment institute of environment studies,
University of Toronto, pp. 933 953.

Ariens, E.J., Simons, A. M. and Offermeier, J. (1976). Interaction between substances in toxicology. In: Introduction to General Toxicology, Academic Press, London, New York, pp: 155 - 171.

Chibuzor, C.A. (1994). Studies on the acute toxicity of ABS detergent against Lepomis gibbous, Msc. thesis. University of Lagos.

Dara, S.S.A. (1993). Text book of Environmental Chemistry and Pollution Control, Chand and Co. Ltd. Ram Nagar, New Delhi 110055.

Don - Pedro, K.N. (1980). A population explosion of Aphis crassivora following DDT application on cowpea (Vigna unguiculata) in Nigeria. Journal of Natural History, 14 (5): 617-619.

Don-Pedro, K.N. and Adegbite, T.O. (1985). Nuvan resistance in field strains of Aedes aegypti in Lagos. Nigerian Environmental Pollution. 38 (A): 19-29.

Don-Pedro, K.N. (1993). Laboratory evaluation of Termite activity of malathion, nuvan and camphor. International Pest Control, 26 (6): 160-162.

Don-Pedro, K.N. (1989). Mode of action of fixed oils against eggs of Callosobrochus masculatus. Pestic. Sci. 26: 107-115.

Enajekpo, H. (2002). Joint action toxicity of spent lubricant oil (SLO) and insecticide against selected brackish water animals of the Lagos lagoon. PhD Thesis, University of Lagos. 288pp. 
Farkas, A., Salanki, J. and Specziar, A. (2002). Relation between growth and the heavy metals concentrations in organs of bream, Abramisbrama L. populating lake Blaton. Arch. of Environ. Contam. Toxicol. 43(2): $236-243$.

Finney, D.J. (1971). Probit analysis. $3^{\text {rd }}$ Edition. Cambridge University Press, London, pp: 318

Lawal, M.O. and Samuel, O.B. (2010). Investigation of Acute Toxicity of Pirimiphos-Methyl $\quad\left(\right.$ Actellic $^{\circledR}$, $25 \%$ EC) on Guppy (Poecilia reticulata, Peters, 1859). Pakistan Journal of Biological Sciences, 13: 405-408.

Hewlett, P.S. and Plackett, R.L. (1959). A unified theory for quantal response to mixtures of drugs, noninteractive action. Biometrics, 15(4): $591-610$.

Mahmut, S.S., Rabia, E.F. and Oner, K. (2005). Investigation of acute toxicity of chlorpyrifos-methyl on guppy, Poecilia reticulata. Chemosphere, 60: 93-96.

Medeiros, L.S., Souza, J.P., Winkaler, E.U., Cruz, C., Souza-Junior, S.C. and Machado-Neto, J.G. (2013). Acute toxicity and environmental risk of teflubenzuron to Daphnia magna, Poecilia reticulata and Lemna minor in the absence and presence of sediment. $J$. of Environmental Science, Health B. 48(7):600-6. doi: 10.1080/03601234.2013.775000.

Mehmet, Y., Alli, G. and Kazim, E. (2004b). Acute toxicity of alphacypermethrin to guppy (Poecilia reticulata, Peter, 1859). Chemosphere, 56: 381-385
Mhadhbi, L. and Beiras, R. (2012) Acute Toxicity of Seven Selected Pesticides (Alachlor, Atrazine, Dieldrin, Diuron, PirimiphosMethyl, Chlorpyrifos, Diazinon) to the Marine Fish (Turbot, Psetta maxima). Water, Air and soil pollution, 223: 5917. doi:10.1007/s11270-012-1328-9.

Ogundiran, M.A., Fawole, O.O. and Adewoye, S.O. (2007). Effects of Soap and Detergent Effluents on the Haematological Profiles of Clarias gariepinus. Science Focus, 12(1): 84-88.

Ogundiran M.A, Fawole, O.O., Adewoye, S.O. and Ayandiran, T. A. (2009) Pathologic Lesions in the Gills Structures of Clarias gariepinus on exposure to sublethal concentrations of soap and detergent effluents. J. Cell and Animal Biol., 3(5): 078-082.

Ogundiran, M.A., Fawole O.O., Adewoye, S.O. and Ayandiran, T.A. (2010). Toxicological impact of detergent effluent on juvenile of African Catfish (Clarias gariepinus) (Buchell 1822). Agric. Biol. J. N. Am., 1(3): 330-342.

Okpokwasili, G.O. and Nwabuzor, C.N. (1988). Primary biodegradation of anionic surfactants in laundry detergents. Chemosphere, 17: 21752182.

Oyekunle, O. (1996). Single and joint action toxicity of nuvan and aldrin against Batangalebretonis.M.Sc Thesis. University of Lagos.

Otitoloju, A.A. (2002). Evaluation of joint action toxicity of binary mixtures of heavy metals against the mangrove periwinkle Tympanatonus fuscatus var. radula 
(L.). Ecotoxicol. Environ. Safety, 53(3): 404-415

Otitoloju, A.A. (2005). Crude oil plus dispersants: Always a boon or bane? Ecotoxicol. Environ. Safety, 60(2): $198-202$.

Otitoloju, A.A. and Okusada, B.O. (2003). Impact of waste materials generated by roadside mechanics and panelbeaters against gutter dwelling fish, Poecilia reticulata. The Zoologist, 2(2): 46 - 54.

Polat, H., Erkoc, F.U., Viran, R. and Oner (2002). Investigation of acute toxicity of beta-cypermethrin on guppies Poecilia reticulata. Chemosphere, 49: 39-44.

Rukiye, V., U. E., Figen, P.H and Oner, K. (2003). Investigation of acute toxicity of deltamethrin on guppies (Poecilia reticulata). Ecotoxicol. Environ. Saf., 55: 82-85.

Swisher, R.D (1975). Surfactants: from recalcitrant to docile. In: Proc. International iodegradation Symposium (Eds.) Sharpely JM, Kaplan AM, pp. 853-865.

Warne, M.S.J. and Schifko, A.D. (1999). Toxicity of laundry detergent components to a freshwater cladoceran and their contribution to detergent toxcicty.Ecotoxicol. Environ. Saf., 44(2): 196 - 206.

Wigglesworth, B. (1976). Evaluation of pesticide poisoning on special trout. Sun press (Pvt). Ltd. New Delhi, 340pp. 